\title{
Duration of immunity acquired by vaccination with the live attenuated vaccine Avishield IB H120 against infectious
} bronchitis virus in SPF chickens

Lana Ljuma Skupnjak*, Anto Vrdoljak and Nikol Očuršćak

\begin{abstract}
The most effective means of controlling infectious bronchitis in poultry is by vaccination. Live attenuated vaccines based on the H120 strain (Mass serotype) are the most commonly used vaccines. Since vaccination is often performed in the hatchery, long duration of immunity is preferred. Avishield IB H120, a live attenuated vaccine based on the strain H120 is registered across the European Union and other countries, and has a declared immunity period of up to 5 weeks after vaccination. This study presents the
\end{abstract}

results of an additional survey demonstrating protection against challenge with the IBV strain M41 up to 8 weeks after a single vaccination with Avishield IB H120. Seven weeks after vaccination, $94 \%$ of chickens vaccinated by spray were protected against the challenge. Eight weeks after vaccination, $80 \%$ of spray vaccinated chickens and $75 \%$ of orally vaccinated chickens were still protected against the challenge with virulent IBV.

Key words: infectious bronchitis virus; vaccination; duration of immunity

\section{Introduction}

Though discovered 80 years ago, infectious bronchitis virus (IBV) still causes pronounced economic losses in the poultry industry worldwide (Toro et al., 2012). Both live and inactivated vaccines are used to vaccinate chickens against

IBV (Jordan, 2017). The most widely used vaccine strain is H120 (Cook et al., 2012), which belongs to the Massachusetts serotype and has been used all over the world for more than 50 years (Bijlenga et al., 2004).

Lana LJUMA SKUPNJAK*, mag. ing. biotechn., (Corresponding author, e-mail: lana.ljuma.skupnjak@ dechra.com), Anto VRDOLJAK, PhD, Nikol OČURŠĆAK, DVM, Genera Inc. (part of Dechra Pharmaceuticals PLC), Rakov Potok, Croatia 
Recently, a new classification system based on the sequence of the S1 gene of IBV has been proposed, combined with an unambiguous lineage nomenclature (Valastro et al., 2016). Accordingly, 32 lineages belonging to 6 different IBV genotypes have been identified for both the H120 and M41 strains classified within the GI-1 genotype.

Many studies have shown crossprotection of H120 strain against heterologous field strains, either in combination with vaccines belonging to other serotypes (e.g. variant strains) (Mohammadi et al., 2014; Bru et al., 2017; Habibi et al., 2017) or even alone (Bijlenga et al., 2004). Given the fact that field strains of the Massachusetts serotype still cause disease in many areas of the world (Jackwood, 2012; Jackwood and Wit, 2013; de Wit et al., 2018), and relying on cross protection, vaccines based on the H120 strain are still the basis for immunoprophylaxis against IBV.

Avishield IB H120 is a live, attenuated vaccine against IBV, based on the strain H120. It has been registered across Europe since 2017 for use in broilers and future layers/breeders from the first day of life.

When developing a vaccine, the manufacturer should follow the requirements of the European Pharmacopoeia and Directive 2001/82/ EC, which lays down the tests and defines the criteria that a vaccine needs to comply with to be granted marketing authorisation in the EU.

Amongst other tests, onset and duration of immunity provided by the vaccine should be tested and specified in the summary of product characteristics.

The onset of protection provided after vaccination with Avishield IB H120 is confirmed already at 10 days after vaccination, reaching full protection (100\%) 21 days after vaccination (Boelm et al., 2018). The same level of protection was observed at 35 days after vaccination.
Since this vaccine is suitable for use in long living birds as well as in broilers, a longer duration of immunity was also investigated. Here we report the results of duration of immunity achieved by vaccination with Avishield IB H120 given to day-old chicks by spray and to 7-dayold chicks by oral administration route.

\section{Materials and Methods}

\section{Viruses}

A live, attenuated vaccine against avian infectious bronchitis virus, based on the H120 strain was used in this study (Avishield IB H120, Genera Inc., Part of Dechra Pharmaceuticals PLC Group). The vaccine is produced in compliance with the European Pharmacopoeia and Directive 2001/82/EC concerning the safety, quality and efficacy of live poultry vaccines.

For demonstration of the duration of immunity, the vaccine was diluted in an appropriate diluent, depending on the route of inoculation, to provide 3.5 $\log _{10} 50 \%$ embryo infectious dose $\left(\right.$ EID $\left._{50}\right)$ per bird, which is the minimum dose recommended for vaccination according to the manufacturer's specification. Challenge of chickens was performed using the virulent IBV strain M41 in a dose of $3.0 \log _{10} \mathrm{EID}_{50}$ per bird.

\section{Experimental design}

\section{Duration of immunity after spray administration}

Two groups of day-old SPF chickens were vaccinated using the minimum dose of Avishield IB H120 by the spray administration route. A third group of day-old SPF chicks was kept as a nonvaccinated control. Each group was housed in a separate HEPA-filtered isolator for chickens. To demonstrate the duration of immunity, 20 chickens from each vaccinated group were challenged with IB M41. Group 1 was challenged 49 days (7 weeks) after vaccination, while 
Table 1. Experimental design of duration of immunity studies for Avishield IB H120 vaccine

\begin{tabular}{|c|c|c|c|c|c|c|}
\hline & \multicolumn{4}{|c|}{ Spray administration } & \multicolumn{2}{|c|}{ Oral administration } \\
\hline $\begin{array}{c}\text { Study } \\
\text { day }\end{array}$ & $\begin{array}{c}\text { Group } 1 \\
20 \text { animals }\end{array}$ & $\begin{array}{c}\text { Group } 2 \\
20 \text { animals }\end{array}$ & \multicolumn{2}{|c|}{$\begin{array}{c}\text { Group } 3 \\
10 \text { animals }\end{array}$} & $\begin{array}{c}\text { Group } 4 \\
20 \text { animals }\end{array}$ & $\begin{array}{c}\text { Group } 5 \\
5 \text { animals }\end{array}$ \\
\hline & \multicolumn{6}{|c|}{ Hatching, Identification } \\
\hline Do & \multicolumn{2}{|c|}{$\begin{array}{c}\text { Vaccination } \\
\text { Avishield IB H120 } \\
\text { Spray administration } \\
\text { method }\end{array}$} & \multicolumn{2}{|c|}{ / } & / & / \\
\hline D7 & \multicolumn{2}{|c|}{ l } & \multicolumn{2}{|c|}{1} & $\begin{array}{c}\text { Vaccination } \\
\text { Avishield IB } \\
\text { H120 } \\
\text { Oral } \\
\text { administration } \\
\text { route }\end{array}$ & / \\
\hline \multirow[b]{2}{*}{ D49 } & \multirow[b]{2}{*}{$\begin{array}{c}\text { Challenge } \\
\text { with IB M41 }\end{array}$} & \multirow[b]{2}{*}{ None } & G3A & G3B & \multirow[b]{2}{*}{ None } & \multirow[b]{2}{*}{ None } \\
\hline & & & $\begin{array}{l}\text { Challenge } \\
\text { with IB M41 }\end{array}$ & None & & \\
\hline D53 & $\begin{array}{c}\text { Euthanasia, } \\
\text { Ciliary } \\
\text { activity of } \\
\text { tracheal } \\
\text { explants }\end{array}$ & / & $\begin{array}{l}\text { Euthanasia, } \\
\text { Ciliary } \\
\text { activity of } \\
\text { tracheal } \\
\text { explants }\end{array}$ & l & / & / \\
\hline D56 & & $\begin{array}{c}\text { Challenge } \\
\text { with IB M41 }\end{array}$ & & $\begin{array}{c}\text { Challenge } \\
\text { with IB M41 }\end{array}$ & / & / \\
\hline D60 & & $\begin{array}{l}\text { Euthanasia, } \\
\text { Ciliary } \\
\text { activity of } \\
\text { tracheal } \\
\text { explants }\end{array}$ & & $\begin{array}{c}\text { Euthanasia, } \\
\text { Ciliary } \\
\text { activity of } \\
\text { tracheal } \\
\text { explants }\end{array}$ & / & / \\
\hline D63 & & & & & $\begin{array}{l}\text { Challenge } \\
\text { with IB M41 }\end{array}$ & $\begin{array}{c}\text { Challenge } \\
\text { with IB M41 }\end{array}$ \\
\hline D67 & & & & & $\begin{array}{l}\text { Euthanasia, } \\
\text { Ciliary activity } \\
\text { of tracheal } \\
\text { explants }\end{array}$ & $\begin{array}{c}\text { Euthanasia, } \\
\text { Ciliary } \\
\text { activity of } \\
\text { tracheal } \\
\text { explants }\end{array}$ \\
\hline
\end{tabular}

group 2 was challenged 56 days (8 weeks) after vaccination. Group 3 (control group, unvaccinated chickens) was divided in two subgroups. The first subgroup (G3A) was used as the control group for Group 1 and received the challenge on the same day as Group 1, while the second subgroup (G3B) was used as the control for Group 2 and received the challenge on the same day as Group 2. Each control subgroup contained 5 chickens.

To assess the protection acquired by vaccination, ciliary activity was examined and scored four days after the challenge as recommended by Ph.Eur. monograph 04/2013:0442, section 2-4-3 Immunogenicity (Ph.Eur., 2013).

\section{Duration of immunity after oral administration}

Duration of immunity after oral administration of Avishield IB H120 was also tested in a separate study. The outline of the study followed essentially the outline presented above, though chickens in the vaccination group (Group 
4) received vaccination by the oral administration route at 7 days of age (Table 1). The challenge was performed in a single testing point, 56 days (8 weeks) after vaccination. A control group of 5 SPF chickens (Group 5) received the challenge on the same day. The level of protection acquired by vaccination was determined by assessment of ciliary activity in the tracheal rings four days after the challenge. The experimental design details are summarized in Table 1.

\section{Ciliary activity}

The ciliary activity of 10 tracheal explants per challenged chicken was examined 4 days after the challenge. Shortly after euthanizing the chickens, the trachea of each chicken was extirpated by removing the skin of the neck. Subsequently, the trachea was disconnected from the surrounding tissues and cut just beneath the head and just above the thorax. Transverse sections of $0.5-1.5 \mathrm{~mm}$ of the trachea were made using a scalpel blade. The transverse tracheal sections were put in wells of a 24-well microtitre plate covered with 0.5 mL DMEM or MEM cell culture medium prewarmed at $35-40{ }^{\circ} \mathrm{C}$ and examined for ciliary activity under the microscope. Ciliary activity of three sections of the upper part, four sections of the middle part and three sections of the lower part of the trachea were examined under 100X magnification. The activity of the cilia in each tracheal section was scored according to Ph.Eur. monograph 04/2013:0442, section 2-4-3 Immunogenicity (Ph.Eur., 2013), as follows:

Score $0: \geq 50 \%$ of the tracheal section shows cilia movement

Score 1: $<50 \%$ of the tracheal section shows cilia movement

A chicken was considered not affected / protected if at least 9 out of 10 tracheal rings showed normal ciliary activity (a score of 0 ). For each chicken, the number of affected tracheal sections was calculated. For each group, the number of affected chickens was calculated.

\section{Animal studies}

In both studies, specific pathogen free (SPF) chickens were used. Animal experiments were conducted in accordance with national and European Union regulations regarding the use and protection of animals used for scientific purposes (Directive 2001/82/EC, Directive 2010/63/EU, Directive 86/609/ EEC, Croatian law OG 102/17, Croatian regulation OG 55/13).

\section{Statistical analysis}

Differences between the levels of protection between vaccinated and nonvaccinated groups were assessed using Fisher's exact $\mathrm{p}$ one-tailed test in Tibco Statistica 13.3.

\section{Results and discussion}

Previously, we showed that the onset of immunity after vaccination with Avishield IB H120 already started 10 days after vaccination and reached full protection $(100 \%)$ at 21 days after vaccination (Boelm et al., 2018). Complete protection was also demonstrated 5 weeks after vaccination.

The objective of this study was to investigate the duration of immunity provided by vaccination with the minimum dose of Avishield IB H120 when applied by spray administration method to day-old chicks and by oral administration method to 7-day-old chicks. There were no clinical signs of disease in the period between vaccination and challenge in any of the groups. During the four days post-challenge, no visual clinical signs or mortality were observed in any of the challenged chickens in the control group for sprayvaccinated chickens.

However, in the control group for orally-vaccinated chickens, 3 out of 5 
Table 2. Protection rates 4 days after challenge with $10^{3.0} \mathrm{EID}_{50}$ of IB M41

\begin{tabular}{|c|c|c|c|}
\hline GROUP & $\begin{array}{c}\text { Age at } \\
\text { vaccination }\end{array}$ & $\begin{array}{c}\text { Age at } \\
\text { challenge }\end{array}$ & $\begin{array}{l}\text { Protection } \\
\text { rate }\end{array}$ \\
\hline Vaccinated by spray with Avishield IB H120 & 1 day & \multirow{2}{*}{49 days } & $94.4 \%$ \\
\hline Non-vaccinated control for spray vaccinated group & $\mathrm{n} / \mathrm{a}$ & & $0 \%$ \\
\hline Vaccinated by spray with Avishield IB H120 & 1 day & \multirow{2}{*}{56 days } & $80 \%$ \\
\hline Non-vaccinated control for spray vaccinated group & $\mathrm{n} / \mathrm{a}$ & & $0 \%$ \\
\hline Vaccinated orally with Avishield IB H120 & 7 days & \multirow{2}{*}{63 days } & $75 \%$ \\
\hline Non-vaccinated control for orally vaccinated group & $\mathrm{n} / \mathrm{a}$ & & $0 \%$ \\
\hline
\end{tabular}

chickens exhibited tracheal rales. There were no clinical signs nor mortality after challenge in any of the vaccinated groups of chickens.

In comparison with the ciliary activity of tracheal explants determined four days after challenge, $94.4 \%$ of chickens vaccinated by spray at 1 day-old were protected 49 days after vaccination, while 56 days after vaccination, $80 \%$ of spray vaccinated chickens and $75 \%$ of orally vaccinated chickens were still protected. Conversely, none of the unvaccinated, control chickens were protected against the challenge and complete ciliostasis was demonstrated (Table 2). Statistical analysis showed there is a significant difference in protection between the vaccinated and control groups of chickens.

In conclusion, Avishield IB H120 provides protection for chickens up to 8 weeks after vaccination, corresponding to the published data for the vaccines based on the H120 vaccine strain (Gough and Alexander, 1979) and for vaccines belonging to the variant serotype GI-13 (Kutle et al., 2020). However, it can be observed that the level of protection decreases when compared to protection rates observed 3 and 5 weeks after vaccination (Boelm et al., 2018), and therefore re-vaccination is often performed in long living birds (Jordan, 2017).

\section{Conclusions}

The Avishield IB H120 live attenuated vaccine based on $\mathrm{H} 120$ vaccinal strain provides protection against M41, a virulent strain of IBV up to 8 weeks after vaccination when administered to day-old chicks by spray or to 7-day-old chicks by oral administration route. The present study showed that adequate protection against Mass serotype IBV field strain can be achieved after a single vaccination with the $\mathrm{H} 120$ vaccine and that the acquired protection may last up to 8 weeks post-vaccination. Taking the short lifespan of broiler chickens into account, it can be concluded that only one vaccination with Mass serotype vaccine is needed for broilers. For broader protection, introducing a second IBV vaccine of distinct serotype is usually recommended.

\section{Disclaimer}

Lana Ljuma Skupnjak, Anto Vrdoljak and Nikol Očuršćak are employed by Genera Inc., part of Dechra Pharmaceuticals PLC, manufacturer of the Avishield IB H120 vaccine.

\section{References}

1. BIJLENGA, G., J. K. COOK, J. JR. GELB and J. J. de WIT (2004): Development and use of the $H$ strain of avian infectious bronchitis virus from the Netherlands as a vaccine: a review. Avian Pathol, 33, 550-557. 
2. BOELM, G. J., J. J. de WIT and L. LJ. SKUPNJAK (2018): Influence of Maternally Derived Antibodies on Vaccination using a IBV H120 Vaccine Virus. J. Vet. Med. Res. 5, 1124.

3. BRU, T., R. VILLA, M. CABANA and H. J. GEERLINGS (2017): Protection of chickens vaccinated with combinations of commercial live infectious bronchitis vaccines containing Massachusetts, Dutch and QX-like serotypes against challenge with virulent infectious bronchitis viruses 793B and IS/1494/06 Israel variant 2. Avian Pathol. 46, 52-58.

4. COOK, J. K. A., M. JACKWOOD and R. C. JONES: The long view: 40 years of infectious bronchitis research. Avian Pathol. 41, 239-250.

5. COUNCIL OF EUROPE. European Pharmacopoeia. $7^{\text {th }}$ ed. Avian infectious bronchitis vaccine (live). 04/2013:0442.

6. COUNCIL OF EUROPE. European Pharmacopoeia. $7^{\text {th }}$ ed. 5.2.7. Evaluation of efficacy of veterinary vaccines and immunosera. 04/2013:50207.

7. DE WIT, J. J., C. CAZABAN, R. DIJKMAN, G. RAMON and Y. GARDIN (2018): Detection of different genotypes of infectious bronchitis virus and of infectious bursal disease in European broilers during an epidemiological study in 2013 and the consequences for the diagnostic approach. Avian Pathol. 47, 140-151.

8. DIRECTIVE 2001/82/EC of the European Parliament and of the Council of 6 November 2001 on the Community code relating to veterinary medicinal products (2001). OJ L311, 1-66.

9. GOUGH, R. E. and D. J. ALEXANDER (1979): Comparison of duration of immunity in chickens infected with a live infectious bronchitis vaccine by three different routes. Res. Vet. Sci. 26, 329-332.

10. HABIBI, M.,V.KARIMI,A.G.LANGEROUDI, S. A. GHAFOURI, M. HASHEMZADEH, R. K. FARAHANI, H. MAGHSOUDLOO, H. ABDOLLAHI and P. SEIFOURI (2017):
Combination of H120 and 1/96 avian infectious bronchitis virus vaccine strains protect chickens against challenge with IS/1494/06 (variant 2)-like infectious bronchitis virus. Acta Virol. 61, 150-160.

11. JACKWOOD, M. W. (2012): Review of infectious bronchitis virus around the world. Avian Dis. 56, 634-641.

12. JACKWOOD, M. W. and S. D. WIT (2013) Infectious Bronchitis. In: Swayne, D. E. (ed). Diseases of Poultry: John Wiley \& Sons, Ltd, 139159.

13. JORDAN, B. (2017): Vaccination against infectious bronchitis virus: a continuous challenge. Vet. Micro. 206, 137-143.

14. KUTLE, L., L. LJ. SKUPNJAK, A. VRDOLJAK, D. JANKOVIĆ, G. J. BOELM, F. KELEMEN, O. Z. ROJS and J. MILLECAM (2020): Efficacy of Infectious Bronchitis GI-13 (793B) Vaccine Candidate Tested According to the Current European Union Requirements and for Cross-Protection Against Heterologous QX-like Challenge. Viral Immunol. doi: 10.1089/vim.2020.0011

15. MOHAMMADI, P., V. KARIMI, M. HASHEMZADEH, A. GHALYANCHI LANGEROUDI, S. A. GHAFOURI, R. KHALTABADI FARAHANI, H. MAGHSOUDLOO and H. ABDOLLAHI (2014): Combination of $\mathrm{H} 120$ and 793/B types of Infectious Bronchitis Virus Vaccine protects chickens against challenge with QX like strain of the virus. Iran. J. Virol. 8, 20-24.

16. TORO, H., V. L. van SANTEN and M. W. JACKWOOD (2012): Genetic diversity and selection regulates evolution of infectious bronchitis virus. Avian Dis. 56, 449-455.

17. VALASTRO V., E.C. HOLMES, P. BRITTON, A. FUSARO, M.W. JACKWOOD, G. CATTOLI and I. MONNE (2016): S1 gene-based phylogeny of infectious bronchitis virus: an attempt to harmonize virus classification. Infect. Genet. Evol. 39, 349-364.

\section{Trajanje imunosti nakon cijepljenja s Avishield IB H120, cjepivom protiv ptičjeg zaraznog bronhitisa}

Mr. sc. Lana LJUMA SKUPNJAK, ing. biotechn., dr. sc. Anto VRDOLJAK, Nikol OČURŠĆAK, dr. med. vet., Genera Inc. (u sastavu Dechra Pharmaceuticals PLC), Rakov Potok, Hrvatska

Cijepljenje je najučinkovitiji način kontrole zaraznog bronhitisa $u$ peradi. Najčešće korištena cjepiva su živa atenuirana cjepiva temeljena na soju H120 (pripadaju Mass serotipu). Budući da se cijepljenje često provodi već u valionici, poželjno je dugo trajanje imunosti. Avishield IB H120, živo atenuirano cjepivo koje sadrži cjepni soj H120, registrirano je u brojnim zemljama Europske unije i na drugim tržištima $s$ deklariranim trajanjem imunosti od 5 tjedana nakon cijepljenja. U ovom radu prikazani su rezultati dodatne studije gdje smo dokazali zaštitu od izazivačke infekcije s patogenim virusom M41 i 8 tjedana nakon cijepljenja s Avishield IB H120 putem spreja ili vode za piće.

Ključne riječi: virus zaraznog bronhitisa, cijepljenje, trajanje imunosti 